\title{
NAZEWNICTWO KAR W KODEKSIE KARNYM REPUBLIKI KOREI W ASPEKCIE TLUMACZENIOWYM KOREAŃSKO-POLSKIM
}

\author{
Bernadetta BALAZY \\ Instytut Językoznawstwa \\ Wydział Neofilologii, Uniwersytet im. Adama Mickiewicza \\ al. Niepodległości 4, 61-874 Poznań, Poland \\ bebalazy@gmail.com
}

\begin{abstract}
Abstrakt: W niniejszym artykule podjęto się próby thumaczenia prawniczego $\mathrm{w}$ odniesieniu do koreańsko-polskiej pary językowej w zakresie prawa karnego materialnego, a dokładniej mówiąc w zakresie nazewnictwa kar kryminalnych. Posłużono się tekstem obecnie obowiązującego koreańskiego kodeksu karnego, a thumaczenie polegało na porównaniu tekstów paralelnych, czyli takich, które istnieją niezależnie od siebie nawzajem (jeden nie jest thumaczeniem drugiego), ale pełnią te same funkcje, z tym że służą użytkownikom różnych języków (Neubert i Shreve 1992, 89). Kodeks Karny Republiki Korei i polska ustawa Kodeks Karny to teksty paralelne, gdyż pełnią tę samą rolę w swojej kulturze prawnej i nie są jednocześnie thumaczeniami. Przy pracy nad thumaczeniem okazało się przydatne także posiłkowanie się innymi polskimi ustawami - Kodeksem Wykroczeń, a także nieobowiązującym już Kodeksem Karnym z 1969 roku. Celem artykułu nie było jedynie dokonanie thumaczenia, ale także przedstawienie chociażby w małym stopniu informacji na temat współczesnego prawa karnego w Korei Południowej. Uznano tę kwestię za istotną ze względu na fakt, że na próżno szukać polskich opracowań dotyczących tej tematyki. W artykule, w całości napisanym w języku polskim, koniecznym było jednak posługiwanie się oryginalnymi terminami koreańskimi, które zostały przedstawione zarówno w pisowni oryginalnej (hangul), jak i za pomocą transkrypcji, ze względu na czytelnika nie znającego języka koreańskiego. Zastosowana transkrypcja to transkrypcja McCune'a - Reischauera (Ogarek - Czoj, 2007, 30). Artykuł jest de facto streszczeniem mojej pracy licencjackiej o tym samym tytule, obronionej w 2013 roku na Wydziale Neofilologii Uniwersytetu im. Adama Mickiewicza w Poznaniu.
\end{abstract}

Słowa kluczowe: nazewnictwo kar kryminalnych w tłumaczeniu, kodeks karny, koreański kodeks karny, prawo karne, tłumaczenie prawnicze, tłumaczenie koreańsko-polskie

\section{NAMES OF PENALTIES IN REPUBLIC OF KOREA'S PENAL CODE IN KOREAN- POLISH TRANSLATION}

Abstract: The article was written with the aim of translating the names of criminal penalties in the Republic
of Korea's Penal Code to the Polish language. The text of the current Korean Penal Code has been
compared with the pararell text of the Polish Penal Code. Although both Penal Codes have similar functions,
the scope of application is slightly different, so the Polish Code of Petty Crimes and the previous Polish
Penal Code (from the year 1969) were used subsidiary. However, the article was written not only for
translatory purposes, but also to initially present an image of South Korean penal law to the Polish readers
since Poland is deficient in such papers. Even though the article is written in Polish, it was essential to use
original Korean names of criminal penalties. Due to Koreans using a different alphabet, the names had to be 
transcripted according to the rules of McCune-Reischauer (Ogarek-Czoj, 2007, 30), to make the Korean words legible for non-Korean readers. The paper is, de facto, a shortened version of my BA paper of the same title.

Keywords: penal law, criminal penalties, Korean-Polish translation, legal translation, Republic of Korea's Penal Code

\section{대한민국 형법상 형벌의 한폴 번역}

초록: 이 기사는 대한민국 형법상 형벌의 한폴 번역할 목표로 작성되었다. 이글은 대한민국 형법과 폴란드 형법의 비교를 통해 번역되었다. 두 형법은 서로 범위가 약간 다르므로 폴란드의 “사소한죄법”과 폴란드의 이전 형법(1969년)이 부수적으로 이용되었다. 그런데 기사의 목표는 번역뿐만 아니라 법률과 관련된 현상을 어느정도 보여주는 것이다. 기사는 완전히 폴란드어이기때문에 형벌에 관한 한국 단어가 사용될 필요성이 있었다. 한국어를 모르는 독자를 위해 그런 단어가 로마자로 쓰여졌다.

기사는 나의 학사 논문의 요약이다.

키워드: 형법, 형벌, 한폴 번역, 법률 번역, 대한민국 형법

\section{Wykaz skrótów:}

\section{Polskie akty prawne:}

KK - Ustawa z dnia 6 czerwca 1997 r. Kodeks Karny. (Dz.U. 1997 nr 88 poz. 553)

KK69 - Ustawa z dnia 19 kwietnia 1969 r. Kodeks Karny (Dz. U. 1969 nr 13 poz. 94; nie obowiązuje obecnie)

KW - Ustawa z dnia 20 maja 1971 r. Kodeks wykroczeń. (Dz.U. 1971 nr 12 poz. 114)

\section{Koreańskie akty prawne:}

KKRK - Ustawa z dnia 3 października 1953 r. Kodeks Karny Republiki Korei

\section{Pozostałe skróty:}

art. - artykuł

OBA - odbiorca bliski A

OBB - odbiorca bliski B

ODA - odbiorca daleki A

ODB - odbiorca daleki B

USJP - Uniwersalny stownik języka polskiego

KRW - won koreański, waluta Republiki Korei

Tłumaczenie prawnicze to procedura lingwistyczna polegająca na zastąpieniu tekstu w źródłowym języku prawnym lub prawniczym tekstem w języku docelowym przy zachowaniu relacji ekwiwalencji. Ekwiwalencja to inaczej relacja odpowiedniości. Thumaczenie prawnicze wymaga od tłumacza znajomości specjalistycznej terminologii z dziedziny prawa. $Z$ jednej strony może to czynić proces tłumaczenia łatwiejszym, niż w przypadku tłumaczeń literackich, bo nie obejmuje obszernej terminologii ogólnej i szerokiego wachlarza synonimów, ale z drugiej strony, kultura prawna danego obszaru (państwa) zakłada pewną wyjątkowość języka prawnego i prawniczego (Jopek-Bosiacka 2006), która może utrudnić zrozumienie, i co za tym idzie, przekład tekstu. Jednak nie 
tylko świadomość i znajomość różnic wynikających z odrębnej kultury prawnej jest tym, co powinno interesować thumacza. Tłumacz tekstów z zakresu szeroko pojętego prawa, jak każdy inny thumacz tekstów specjalistycznych, powinien posiadać wiedzę z kilku dziedzin (Kaczmarek i Matulewska 2008). To bynajmniej nie wszystko - od thumacza wymaga się odpowiedniej ogólnej kompetencji językowej oraz znajomości zasad i technik tłumaczenia.

\section{Strategie thumaczeniowe}

Kierzkowska wyróżnia $\mathrm{w}$ ramach strategii thumaczenia cztery rodzaje ekwiwalencji. Są to: ekwiwalencja denotacyjna, ekwiwalencja konotacyjna, ekwiwalencja pragmatyczna i ekwiwalencja tekstowo-normatywna. Ekwiwalencja denotacyjna jest nastawiona bardziej na tekst źródłowy niż na tekst docelowy. W jej ramach wyrażenie nie posiadające ekwiwalentów tłumaczy się w ten sposób, że odwołuje się do systemu prawnego, dla którego powstał tekst w języku źródłowym. Tym sposobem odbiorca tekstu docelowego otrzymuje ekwiwalent, który oznacza instytucję funkcjonującą w obcej mu kulturze prawnej (i którego może nie zrozumieć lub może zrozumieć niewłaściwie), ale tłumaczenie to jest wierne w tym sensie, że nie przedstawia zmodyfikowanego obrazu rzeczywistości tekstu źródłowego. Ekwiwalencja konotacyjna jest czymś zgoła innym niż ekwiwalencja denotacyjna. Bierze pod uwagę odbiorcę tekstu docelowego w dużo większym stopniu. Jej stosowanie polega na zastąpieniu wyrażenia oznaczającym daną instytucję w języku źródłowym wyrażeniem języka docelowego oznaczającym instytucję najbardziej podobną. Opiera się więc na użyciu konotatów (skojarzeń) znanych odbiorcy. Ten sposób może być bardziej zrozumiały dla odbiorcy, ale jednocześnie nie do końca wiernie przedstawiać rzeczywisty stan wyrażony w tekście źródłowym. Ekwiwalencję pragmatyczną charakteryzuje najwyższe spośród wszystkich czterech odmian nastawienie na odbiorcę. W jej przypadku bowiem to sam odbiorca, ze względu na indywidualne potrzeby, narzuca thumaczowi sposób thumaczenia określonych terminów.

Ekwiwalencja tekstowo-normatywna zakłada istnienie pewnych konwencji na poziomie gramatycznym, frazeologicznym, stylistycznym i rejestru, a poza tym tradycji obowiązujących $\mathrm{w}$ danym języku docelowym. To właśnie na nie ukierunkowane powinno być tłumaczenie przy stosowaniu tego rodzaju ekwiwalencji.

\section{Techniki zapewniania ekwiwalencji dla wyrażeń bezekwiwalentowych}

Należy zaznaczyć, że nie wszystkie wyrażenia da się przetłumaczyć z języka źródłowego na język docelowy w sposób dosłowny. Na gruncie thumaczeń prawniczych często zdarza się tak, że instytucje funkcjonujące w kulturze prawnej państwa A nie mają idealnych odpowiedników w państwie B, a czasem wręcz nie mają ich wcale (wyrażenie nie mające takiego odpowiednika nazywa się wyrażeniem bezekwiwalentowym). Należy wówczas zastosować jedną $\mathrm{z}$ technik zapewniania ekwiwalencji dla takich wyrażeń. To, którą technikę należy zastosować, jest kwestią wyboru dokonywanego przez thumacza. Wybór ten jednak powinien być uzależniony od odbiorcy, dla którego dokonywane jest tłumaczenie. W przypadku thumaczenia prawniczego w aspekcie koreańsko-polskim pojawiają się terminy bezekwiwalentowe, czyli takie, co do których nie istnieje w języku docelowym pojęcie, o którym mowa w języku źródłowym (Kierzkowska 2002, 113). 
Technik w odniesieniu do tłumaczenia prawniczego według Kierzkowskiej jest kilka, a są to: ekwiwalent naturalny daleki, ekwiwalent naturalny bliski, ekwiwalent seminaturalny, kalka leksykalna wyrazowa, zapożyczenie proste, zapożyczenie naturalizowane, ekwiwalent opisowy i ekwiwalent frazeologiczny. Ekwiwalent naturalny daleki to taki, który wywołuje naturalne skojarzenie u odbiorcy, jako że podobna instytucja funkcjonuje w realiach języka docelowego, czyli języka odbiorcy tłumaczenia. Ekwiwalent taki jednak nie do końca odpowiada temu, czym jest dane pojęcie w języku źródłowym, więc może być mylący dla odbiorcy (tak zwany „fałszywy przyjaciel”). Kierzkowska w przypadku tłumaczenia prawniczego podaje przykład w języku angielskim, gdzie limited liability company tłumaczone jest na spółka $\mathrm{z}$ ograniczoną odpowiedzialnością, mimo że nie są to do końca odpowiadające sobie, bliźniacze instytucje (Kierzkowska 2002, 117). Ekwiwalent naturalny bliski, mimo że nie do końca oddaje charakter terminu języka źródłowego, to różni się tym od ekwiwalentu dalekiego, że oddaje istotę danego pojęcia $\mathrm{i}$ jest $\mathrm{w}$ takim znaczeniu powszechnie używany. Inną pozycję ma judge w systemie anglosaskim niż sędzia w systemie polskim (kontynentalnym), ale i tak thumaczenie terminu judge na termin sędzia jest ogólnie przyjęte (Kierzkowska 2002, 119). W przypadku tłumaczenia koreańsko-polskiego trudniej jednak mówić o uzusie, gdyż w porównaniu do pary językowej angielsko-polskiej, para koreańsko-polska jest o wiele rzadziej występującą kombinacją w przypadku tłumaczeń prawniczych. Ekwiwalent seminaturalny to wypadkowa ekwiwalentu naturalnego i cech terminu języka źródłowego. Ekwiwalent seminaturalny zawiera dodatkowe elementy, które mają zapobiegać myleniu terminów, jak by to mogło mieć miejsce przy zastosowaniu ekwiwalentu naturalnego (Kierzkowska 2002, 120). Kalka leksykalna wyrazowa to znaczeniowe odwzorowanie pojęcia z języka źródłowego przy użyciu takich środków, jakimi dysponuje język docelowy. Kalki językowe spotyka się nie tylko w tłumaczeniu prawniczym, a także w języku potocznym. Przykładem jest tłumaczenie value added tax jako podatek od wartości dodanej (Kierzkowska 2002, 121). Zapożyczenie proste to „technika thumaczeniowa polegająca na pozostawieniu w tekście przekładu wyrazu lub zwrotu z języka wyjściowego w niezmienionej formie" (Lukszyn 1993, 399). W przypadku thumaczenia $\mathrm{z}$ języka koreańskiego na język polski byłoby to jednak rozwiązanie nie do końca udane ze względu na różnice $\mathrm{w}$ zapisie $\mathrm{i}$ wymowie. Zapożyczenie naturalizowane $\mathrm{w}$ przeciwieństwie do zapożyczenia prostego zakłada dostosowanie pisowni danego terminu do wymowy zgodnie z zasadami fonetycznymi w języku docelowym. Wadą zarówno zapożyczenia prostego jak i naturalizowanego jest to, że pojecie pozostaje nadal kompletnie niezrozumiałe dla odbiorcy dalekiego (Kierzkowska 2002, 122). W przypadku języka koreańskiego, który jest językiem o zupełnie innej genealogii niż język polski, zastosowanie powyższych dwóch rozwiązań nie wywoła żadnych skojarzeń u odbiorcy dalekiego. Ekwiwalent opisowy wydaje się być dobrym rozwiązaniem jeśli odbiorcą jest nie-prawnik. Za pomocą opisu w języku docelowym danego pojęcia $z$ języka źródłowego oddaje się jego istotę. Ze względu jednak na opisowy charakter czyni to tekst o wiele dłuższym niż tekst oryginału, jeśli okaże się że dane pojęcie wielokrotnie powtarza się w tekście (Kierzkowska 2002, 122). Ekwiwalent frazeologiczny „może mieć formę wyrażenia czasownikowego, które oznacza wykonywanie jakiejś czynności” (Kierzkowska 2002, 123). Nie ma jednak dla 
pracy większego znaczenia stosowanie tego ekwiwalentu, gdyż tłumaczone są pojęcia złożone z jednego słowa, a nie większe segmenty zdaniowe.

\section{Pojęcie kary, kary kryminalnej i sankcji w polskim prawie karnym}

Przedmiotem badań są polskie i koreańskie nazwy kar znajdujące się w odpowiednich dla danego systemu prawa tekstach aktów prawnych oraz ich tłumaczenie w aspekcie koreańsko-polskim. W związku z tym należy określić czym jest kara w rozumieniu prawa karnego. Kara, o jakiej mowa w ramach prawa karnego, to tzw. kara kryminalna i jest to środek przymusu państwowego, który ma na celu zwalczanie przestępczości. (Bojarski 2012). Nie-prawnik może mieć trudności z rozróżnieniem pojęć sankcji, sankcji karnej, kary czy kary kryminalnej, które używane są w ramach nauki prawoznawstwa i prawa karnego oraz w innych dziedzinach nauki prawa. Należy zatem krótko wyjaśnić na czym polega różnica między tymi wszystkimi pojęciami, gdyż nie są one synonimami. Sankcja to ,dolegliwość przewidziana za niezrealizowanie jakiejś normy (zło przewidziane za jej niezrealizowanie)" (Wronkowska 2005, 123). Sankcja karna jest jednym z trzech jej typów i jest to ,zło wyrządzone przez państwo temu, kto dopuszcza się przestępstwa” (Wronkowska 2005, 125). Inne typy sankcji to sankcja nieważności i sankcja egzekucji (Wronkowska 2005, 125), które nie stanowią przedmiotu zainteresowania pracy, ale należy zasygnalizować ich istnienie dla podkreślenia, że używanie określenia „,sankcja” w odniesieniu do tylko jednego jej typu może powodować nieporozumienia. Jeśli chodzi o umiejscowienie sankcji karnej w normie prawnej, to ,sankcję karną uznaje się za część normy kompetencyjnej (sankcjonującej)” (Burzyński 2008, 19). Terminy „kara” i „sankcja karna” w ramach nauki prawa karnego materialnego mogą być stosowane wymiennie. Należy także omówić znaczenie słowa kryminalny w odniesieniu przede wszystkim do terminu „,kara kryminalna", które występuje w pracy. Kary przewidywane przez prawo karne określa się bowiem terminem „,kary kryminalne”. O karze kryminalnej mówi się więc w przypadku kary, która wymierzana jest za przestępstwo. Zachodzi konieczność rozróżnienia kar istniejących w systemie prawnym, poza karami z KK istnieją bowiem kary porządkowe, dyscyplinarne itd. (Marek i Lachowski 2011, 145).

\section{Kary w polskim prawie karnym}

Karami w świetle art. 32 Kodeksu Karnego są: kara grzywny, kara ograniczenia wolności, kara pozbawienia wolności, kara 25 lat pozbawienia wolności i kara dożywotniego pozbawienia wolności. Poniżej zostały one szerzej scharakteryzowane.

Grzywna to „kara pieniężna nakładana przez organy sądowe lub administracyjne”. Stanowi karę na podstawie art. 32 Kodeksu Karnego. Art. 33 określa sposób wymierzania tej kary. Wymierza się ją w stawkach dziennych, których liczba i wysokość może być różnie ustalana - w zależności od przestępstwa (stanowi o tym przepis części szczególnej, dotyczący określonego przestępstwa) ilość i wysokość stawek jest różna. Najniższa liczba stawek wynosi 10, a najwyższa 540. Grzywna jest dolegliwością powodującą uszczuplenie majątku sprawcy, tak więc organ orzekając tę karę musi brać pod uwagę, zgodnie $\mathrm{z}$ art. $33 \S 3 \mathrm{KK}$ dochody sprawcy, jego warunki osobiste, rodzinne, stosunki majątkowe i możliwości zarobkowe. Jedna stawka dzienna to minimalnie 10 złotych, a maksymalnie 2000 złotych. Na potrzeby niniejszej 
pracy, mimo że kodeks nie operuje pojęciem kwoty, a jedynie stawki i wysokości stawki, należy zaznaczyć, że zgodnie z tym artykułem najniższa grzywna orzeczona za przestępstwo może wynosić teoretycznie 100 złotych, a maksymalna 1080000 złotych (jeśli przepisy szczególne nie stanowią inaczej). O tym, czy grzywna jest karą najmniej dolegliwą spośród wymienionych, można by dyskutować, zważając na to, jak wysoka może ona być. Przewidziana jest ona jednak za przestępstwa o najlżejszym ciężarze gatunkowym. Zagrożone nią jest na przykład przestępstwo z art. 193 KK (naruszenie miru domowego), art. $261 \mathrm{KK}$ (znieważenie pomnika) itd.

Ograniczenie wolności jest karą wymierzaną „sprawcom (...) mniej groźnych przestępstw, polegającą między innymi na tym, że skazany pozostaje na wolności, ale nie może bez zgody sądu zmienić miejsca pobytu" (USJP, 1214). Kara ograniczenia wolności jest usytuowana pomiędzy karą grzywny a karami pozbawienia wolności, co wskazuje, że jej dolegliwość jest mniejsza niż kar pozbawienia wolności, a większa niż grzywny (Giętkowski 2007, 41). Podstawą prawną dla kary ograniczenia wolności w KK jest art. 32 KK. Przepisy szczególne, art. 35, art. 36 i art. 37 KK, określają wymiar, sposób wykonania i obowiązki skazanego na tę karę.

Pozbawieniem wolności nazywa się ,karę zasadniczą wymierzoną za przestęppstwo, polegającą na umieszczeniu przestępcy w zakładzie karnym" (USJP, 497). Podobnie jak w przypadku wszystkich pozostałych kar w KK, podstawą prawną jest art. 32 KK. Precyzując definicję słownikową, kara pozbawienia wolności obejmuje umieszczenie skazanego w zakładzie karnym na okres od trzech miesięcy do piętnastu lat. Kary pozbawienia wolności o bardziej dolegliwym charakterze to: kara 25 lat pozbawienia wolności oraz kara dożywotniego pozbawienia wolności, które w KK są karami odrębnymi.

Kara 25 lat pozbawienia wolności została wyodrębniona spośród terminowych kar pozbawienia wolności jako kara stosunkowo surowa. Zagrożone są nią podobnie ciężkie lub wręcz te same przestępstwa co te zagrożone karą dożywotniego pozbawienia wolności (np. art. $127 \mathrm{KK}$ - podejmowanie działań zmierzających do pozbawienia Rzeczypospolitej Polskiej niepodległości).

Kara dożywotniego pozbawienia wolności to w polskim systemie prawnym obecnie najsurowsza $\mathrm{z}$ kar. Jej podstawę stanowi art. $32 \mathrm{KK}$. Kara ta polega na dożywotnim więzieniu (USJP, 688). Zagrożone są nią najcięższe przestępstwa, takie jak prowadzenie wojny napastniczej (art. $117 \mathrm{KK}$ ), stosowanie środka masowej zagłady zakazanego przez prawo międzynarodowe (art. $120 \mathrm{KK}$ ).

Poza karami można orzec wobec skazanego wymienione w art. 39 KK środki karne. Środki karne orzekane są obok kary lub w określonych przypadkach zamiast niej (Zoll i Wróbel 2010, 33). Jest ich trzynaście i są to:

1. pozbawienie praw publicznych,

2. zakaz zajmowania określonego stanowiska, wykonywania określonego zawodu lub prowadzenia określonej działalności gospodarczej, 
3. zakaz prowadzenia działalności związanej z wychowaniem, leczeniem, edukacją małoletnich lub opieką nad nimi,

4. obowiązek powstrzymania się od przebywania w określonych środowiskach lub miejscach, zakaz kontaktowania się z określonymi osobami, zakaz zbliżania się do określonych osób lub zakaz opuszczania określonego miejsca pobytu bez zgody sądu,

5. zakaz wstępu na imprezę masową,

6. zakaz wstępu do ośrodków gier i uczestnictwa w grach hazardowych,

7. nakaz opuszczenia lokalu zajmowanego wspólnie z pokrzywdzonym,

8. zakaz prowadzenia pojazdów,

9. przepadek,

10. obowiązek naprawienia szkody lub zadośćuczynienia za doznaną krzywdę,

11. nawiązka,

12. świadczenie pieniężne,

13. podanie wyroku do publicznej wiadomości.

Dla pracy znaczenie mają tylko wybrane ze środków karnych, gdyż po części ich konstrukcja odpowiada temu, co w KKRK jest zakwalifikowane jako kara. Ze względu na to wśród wymienionych środków karnych na szczególną uwagę zasługują trzy środki scharakteryzowane poniżej, to znaczy pozbawienie praw publicznych, zakaz zajmowania określonego stanowiska, wykonywania określonego zawodu lub prowadzenia określonej działalności gospodarczej oraz przepadek przedmiotów.

Pozbawienie praw publicznych to środek karny związany $\mathrm{z}$ tzw. moralnym potępieniem sprawcy (Gardocki 2010, 171). Wiąże się on z utratą praw dotyczących sfery publicznej, a więc:

1. utrata czynnego i biernego prawa wyborczego do organów władzy publicznej, organów samorządu zawodowego czy gospodarczego

2. utrata prawa do udziału w wymiarze sprawiedliwości

3. utrata prawa do pełnienia funkcji w organach i instytucjach państwowych i samorządu terytorialnego lub zawodowego (Bojarski 2012, 274).

Zgodnie z art. 40. KK, pozbawienie praw publicznych jest orzekane w przypadku gdy sprawca dopuszcza się popełnienia przestępstwa w wyniku motywacji zasługującej na szczególne potępienie. Taką motywacją może być ,nieusprawiedliwiona okolicznościami chęć zemsty, chęć poniżenia lub znęcania się nad inną osobą, a także nieusprawiedliwiona szczególną sytuacją chęć osiągnięcia korzyści majątkowej z przestępstwa” (Gardocki 2010, 172).

Kolejny środek karny, o którym mowa w art. 41. KK to zakaz zajmowania określonego stanowiska, wykonywania określonego zawodu lub prowadzenia określonej działalności gospodarczej. Orzeka się go, jeżeli zajdzie jedna z dwóch wymienionych okoliczności:

1. jeżeli sprawca przy popełnieniu przestępstwa nadużył stanowiska lub zawodu;

2. jeżeli sprawca okazał, że zajmowanie stanowiska lub wykonywanie zawodu zagraża istotnym dobrom chronionym prawem (Gardocki 2010, 172). 
Kwestię środka karnego zwanego przepadkiem przedmiotów regulują art. 44 i 45. KK. Zgodnie z nimi, przepadek przedmiotów dotyczy:

1. przedmiotów pochodzących bezpośrednio z przestępstwa;

2. przedmiotów, które służyły lub były przeznaczone do popełnienia przestępstwa;

3. przedmiotów, których wytwarzanie, posiadanie, obrót, przesyłanie, przenoszenie lub przewóz jest zakazany;

4. przepadku korzyści majątkowych pochodzących chociażby pośrednio z popełnienia przestępstwa. W przypadku tego środka karnego, sąd ma obowiązek go orzec w przypadku przedmiotów z punktu pierwszego, a w przypadku pozostałych (czyli punktów 2-4) może go orzec (Bojarski 2012, 279).

\section{Zagadnienie prawa wykroczeń w prawie polskim}

Kodeks Wykroczeń z 20 maja 1971 reguluje materialne prawo wykroczeń w Polsce. Od prawa karnego różni się przede wszystkim tym, że dotyczy czynów o mniejszej szkodliwości społecznej niż przestępstwa, czyli tak zwanych wykroczeń (Marek 2012, 24). Ze względu na podobieństwo pewnych instytucji w koreańskim prawie karnym do instytucji istniejących $\mathrm{w}$ polskim prawie wykroczeń, przedstawiono poniżej krótką charakterystykę kary aresztu, kary grzywny oraz jednego ze środków karnych w prawie wykroczeń - przepadku przedmiotów.

Kara aresztu to kara najsurowsza w świetle KW (Marek 2012, 79). Areszt, zgodnie z art. $19 \mathrm{KW}$ trwa od pięciu do trzydziestu dni. Znajduje się w KW, gdyż zagrożone są nim wykroczenia i, mimo że jego charakter jest kontrowersyjny (Marek 2012,79), to jego dolegliwość jest i tak dużo mniejsza niż dolegliwość kary pozbawienia wolności z KK.

Grzywna z KW swoją nazwą przypomina karę grzywny z KK. Jej charakter również jest podobny - chodzi o karę pieniężną. Różnią się one (poza tym, że jedna dotyczy przestępstw, a druga wykroczeń) wysokością. Grzywna z art. $24 \mathrm{KW}$ jest dużo niższa niż kara grzywny z KK. Poza tym, prawo wykroczeń nie operuje omawianym wcześniej pojęciem stawek dziennych. Wysokość grzywny z KW podawana jest kwotowo, przy czym wysokość grzywny z art. $24 \mathrm{KW}$ to minimalnie 20, a maksymalnie 5000 złotych. Jest ona podstawowym środkiem w odniesieniu do karania za wykroczenia (Marek 2012, 83).

Podobnie jak w KK, w KW znajduje się środek karny o nazwie ,przepadek przedmiotów", którego konstrukcja jest analogiczna do jego odpowiednika z KK. Podstawą prawną jest art. $30 \S 1 \mathrm{KW}$ i stanowi on, że przepadek przedmiotów obejmuje:

1. narzędzia lub inne przedmioty, które służyły lub były przeznaczone do popełnienia wykroczenia;

2. przedmioty pochodzące bezpośrednio lub pośrednio z wykroczenia, których przepadek orzeka się jeżeli przepis szczególny tak stanowi (Marek 2012, 89). 


\section{Kary w koreańskim prawie karnym}

Obecnie obowiązujący Kodeks Karny Republiki Korei pochodzi z roku 1953 i był wielokrotnie nowelizowany (Ryu 1957, 275). Składa się z dwóch części, każda odpowiednio po 4 i 42 rozdziały, z czego część druga stanowi odpowiednik części szczególnej polskiego KK, czyli zawiera przepisy dotyczące konkretnych typów przestępstw, ich charakterystykę oraz karę, jaką są zagrożone. Kwestię katalogu kar reguluje art. $41 \mathrm{KKRK}$, na podstawie którego przewiduje się następujące dziewięć kar: sahyŏng (사형), jingyŏk (징역), gŭmgo (금고), jagyŏk sangshil (자격상실), jagyŏk jŏngji( 자격정지), pŏlgŭm (벌금), guryu (구류), gwaryo (과료) i molsu (몰수). Karom poświęcony jest cały rozdział trzeci części pierwszej KKRK, który składa się z ośmiu sekcji. W rozdziale trzecim prawodawca określa wcześniej wspomniane rodzaje kar, ich surowość (sekcja I), a także czynniki mające wpływ na wymierzenie określonej sankcji karnej (sekcja II).

Sahyŏng to najsurowsza z kar przewidzianych w KKRK. Polega na pozbawieniu życia skazanego (Kim, Lee I. i Lee K. 2007, 172). Charakteryzuje ją przede wszystkim art. 66. KKRK, który mówi o sposobie wykonania kary - następuje ono przez powieszenie w więzieniu. Zagrożone są nią najcięższe przestępstwa, zwłaszcza te związane z insurekcją, ale także inne, na przykład przestępstwo z rozdziału XXIV KKRK, jakim jest zabójstwo (tzw. zwykłe) lub zabójstwo członka rodziny z art. 250 KKRK. Postulowano zniesienie kary śmierci w Korei, ale wymagałoby to zmiany konstytucji, jako że kara ta ma swoją podstawę również w ustawie zasadniczej (Kim i Jang 2000, 328).

Kolejną karą jest jingyŏk, która należy to trójki tzw. kar pozbawienia wolności (jayuhyŏng; 자유형) razem z gŭmgo i guryu (Kim i Jang 2000, 328). Szczegółowo reguluje ją art. $67 \mathrm{KKRK}$. Polega na tym, że skazany zostaje pozbawiony wolności przez osadzenie w więzieniu oraz nakłada się na niego obowiązek wykonywania pracy. Maksymalna wysokość kary to dożywocie, a następnym najbardziej dolegliwym wymiarem tej kary jest pozbawienie wolności z przymusową pracą więzienną na okres 25 lat (Kim i Jang 2000, 328).

Gŭmgo to kolejna z kar, które wiążą się z pozbawieniem skazanego wolności. Tym rożni się od jingyŏk, że nie przewiduje się przymusowej pracy więźnia w obozie pracy, tak więc jest karą mniej dolegliwą, a jednocześnie karą zagrażającą za mniejszą liczbę przestępstw, mniej „popularną”. Podstawą prawną jest art. 41 KKRK i art. 46 KKRK, mówiący o tym, że kara ta może wynosić minimalnie jeden a maksymalnie trzydzieści dni.

Następną w kolejności karą jest jagyŏk sangshil. Kara ta ma związek z dożywotnią utratą praw publicznych. Należy do grupy kar o nazwie myŏngyehyŏng (명예형), czyli kar o charakterze honorowym. Kara ta jest karą w pewien sposób zależną od orzeczonej kary głównej, na kształt środków karnych z KK, lecz w KKRK jest wyraźnie zakwalifikowana jako kara, a więc nie można orzec jedynie jej za popełnienie przestępstwa (tym bardziej, że w KKRK nie ma ani jednego przestępstwa zagrożonego 
tylko jagyŏk sangshil). Orzeka się ją, zgodnie z art. 43 KKRK w przypadku, gdy skazany:

1. zostaje skazany na karę śmierci;

2. zostaje skazany na dożywotnie pozbawienie wolności dowolnego typu.

Do praw publicznych, jakich jest w związku z jagyŏk sangshil pozbawiony skazany zalicza się zgodnie z art. 43 KKRK:

1. pozbawienie prawa do bycia funkcjonariuszem publicznym,

2. pozbawienie praw wyborczych (czynnego i biernego),

3. utrata uprawnień do prowadzenia działalności gospodarczej,

4. utrata uprawnień do pełnienia funkcji dyrektora, rewidenta, kierownika osoby prawnej, a także członka rady nadzorczej lub kuratora osoby prawnej (Kim i Jang 2000, 330).

Łagodniejszą odmianą kary niż jagyŏk sangshil, która ma na celu zawieszenie skazanego w prawach publicznych, jest jagyŏk jŏngji. Jest to druga i ostatnia z kar honorowych - myŏngyehyŏng. Dotyczy tych samych praw, co jej surowsza odmiana. Kara ta jednak dużo częściej pojawia się w kodeksie jako grożąca za popełnienie przestępstwa. W przeciwieństwie do jagyŏk sangshil, możliwość orzeczenia tej kary jest wskazana w przepisach części szczególnej KKRK, czyli przy danym przestępstwie, jeśli jest nią zagrożone.

Pŏlgŭm przedstawia się jako karę pieniężną. Nie jest jedyną tego typu karą w koreańskim prawie karnym. Oprócz pŏlgŭm karą pieniężną jest też gwaryo, a różnica między nimi polega na stopniu w jakim są one dolegliwe dla sprawcy, przy czym pŏlgŭm jest karą surowszą. Podstawę prawną stanowi art. $41 \mathrm{KKRK}$, a przepisem szczególnym dotyczącym przedziału kwotowego jest art. 45 KKRK. Przepis ten nie przewiduje kwoty maksymalnej, a jedynie kwotę minimalną, która opiewa na 50 tysięcy wonów koreańskich. Pŏlgŭm jest karą, którą zagrożone jest bardzo wiele przestępstw w KKRK, niemal w każdym rozdziale w części szczególnej kodeksu pojawia się zagrożenie akurat tą karą pieniężną.

Trzecia z kar związanych z utratą wolności to guryu. Ze wszystkich kar w tej grupie jest najmniej dolegliwa, ponieważ jej wymiar to, na podstawie art. 46 KKRK, maksymalnie trzydzieści, a minimalnie jeden dzień. Ze względu na swą mniejszą dolegliwość oczywiście zagrożone są nią przestępstwa gatunkowo lżejsze. W KKRK nie występuje zbyt wiele przestępstw zagrożonych tą karą. W przeciwieństwie do jingyŏk nie obejmuje wykonywania przymusowej pracy (Kim i Jang 2000, 329).

Druga i ostatnia $\mathrm{z}$ kar pieniężnych $\mathrm{w}$ art. 41 KKRK to gwaryo. Podobnie jak pŏlgŭm jej wysokość podana jest w kodeksie kwotowo, ale gwaryo przewidywana jest na minimalnie $2000 \mathrm{KRW}$, a maksymalnie na $50000 \mathrm{KRW}$. 
Ostatnią z kar w katalogu z art. 41 KKRK jest molsu. Kara ta ma związek z pozbawieniem (konfiskatą) skazanego mienia. Jest ona wraz z karami pŏlgŭm i gwaryo traktowana jako kara o charakterze majątkowym, tzw. jaesanhyŏng (재산형) (Kim i Jang 2000, 329). Konfiskacie w ramach tej kary podlegają:

1. przedmioty, którymi sprawca posłużył się do popełnienia przestępstwa albo które miały służyć do popełnienia przestępstwa,

2. przedmioty uzyskane lub wyprodukowane $\mathrm{w}$ drodze przestępstwa,

3. przedmioty otrzymane w zamian za przedmioty wymienione powyżej.

O tym, kiedy orzeka się tę karę, decyduje przepis szczególny. Swoim charakterem przypomina środek karny, ale KKRK nie operuje takim pojęciem.

\section{Tabele porównawcze}

Poniżej przedstawiono tabele porównujące podobne instytucje w prawie koreańskim i prawie polskim. Przy doborze cech przyjęto następujące założenia:

1. Częstość zagrożenia karą mierzono częstością zagrożenia danych grup przestępstw określoną karą wg wzoru (ilość rozdziałów części szczególnej kodeksu, w których pojawia się zagrożenie daną karą/całkowita liczba rozdziałów w części szczególnej kodeksu). Po zamianie ułamków zwykłych na udział procentowy częstość występowania kary mierzy się następująco:

i) $100 \%$ - 80\% - bardzo częste występowanie zagrożenia daną karą (bardzo często)

ii) $80 \%-50 \%$ - częste występowanie zagrożenia daną karą (często)

iii) $50 \%-20 \%$ - rzadkie występowanie zagrożenia daną karą (rzadko)

iv) $20 \%-0 \%$ - bardzo rzadkie występowanie zagrożenia daną karą (bardzo rzadko).

2. W przypadku polskiego KK pominięto przestępstwa z części wojskowej, mimo że jest ona integralną częścią KK, jako że odpowiednik koreański - Kodeks Karny Wojskowy Republiki Korei nie stanowi przedmiotu zainteresowania tej pracy, a więc w tej sytuacji przestępstwa wojskowe z KK nie mają szczególnej doniosłości.

3. Rubryka „przepis szczególny” tyczy się przepisów szczególnych z KK, KW lub KKRK.

4. Zestawiono ze sobą kary pozbawienia wolności z KK z karami podobnymi z KKRK. Wyjątkiem jest kara aresztu z KW zestawiona z guryu z KKRK ze względu na ich charakter i wysokość.

5. Grzywna i kary pieniężne z KKRK zostały porównane w ramach jednej tabeli ze względu na ich majątkowy charakter.

6. Wysokość kar pieniężnych została podana dla obu systemów prawnych w polskich złotych dla łatwiejszego i szybszego porównania ich dolegliwości.

7. W przypadku środków karnych lub kar, których nie orzeka się samodzielnie, rubrykę „częstość zagrożenia karą” uzupełniono o podstawę prawną do orzeczenia danej sankcji. 
Comparative Legilinguistics 22/2015

Tabela 1: pŏlgŭm i gwaryo a grzywny z KK i KW

\begin{tabular}{|c|c|c|c|c|}
\hline Cecha & Grzywna z KK & Grzywna z KW & pŏlgŭm & gwaryo \\
\hline Podstawa prawna & Art. 32 KK & Art. 18 KW & Art. 41 KKRK & Art. 41 KKRK \\
\hline Przepis szczególny & Art. 33 KK & Art. 24 KW & Art. 45 KKRK & Art. 47 KKRK \\
\hline $\begin{array}{c}\text { Maksymalna } \\
\text { wysokość w złotych }\end{array}$ & 1080000 & 5000 & $\begin{array}{c}\text { Brak górnej usta- } \\
\text { wowej granicy }\end{array}$ & ok. 150 \\
\hline $\begin{array}{c}\text { Minimalna wysokość } \\
\text { w złotych }\end{array}$ & 100 & 20 & ok. 150 & ok. 6 \\
\hline $\begin{array}{c}\text { Częstość zagrożenia } \\
\text { karą }\end{array}$ & Bardzo często & Bardzo często & Bardzo często & Bardzo rzadko \\
\hline $\begin{array}{c}\text { Sposób wymierzania/ } \\
\text { podawania wysokości }\end{array}$ & $\begin{array}{c}\text { W stawkach } \\
\text { dziennych }\end{array}$ & Kwotowo & Kwotowo & Kwotowo \\
\hline
\end{tabular}

Tabela 2: Kary pozbawienia wolności

\begin{tabular}{|c|c|c|c|c|c|}
\hline Cecha & $\begin{array}{c}\text { Kara } \\
\text { pozbawienia } \\
\text { wolności }\end{array}$ & $\begin{array}{c}\text { Kara } 25 \text { lat } \\
\text { pozbawienia } \\
\text { wolności }\end{array}$ & $\begin{array}{c}\text { Kara } \\
\text { dożywotniego } \\
\text { pozbawienia } \\
\text { wolności }\end{array}$ & 금고 & 징역 \\
\hline $\begin{array}{l}\text { Podstawa } \\
\text { prawna }\end{array}$ & Art. $32 \mathrm{KK}$ & Art. $32 \mathrm{KK}$ & Art. $32 \mathrm{KK}$ & $\begin{array}{l}\text { Art. } 41 \\
\text { KKRK }\end{array}$ & $\begin{array}{l}\text { Art. } 41 \\
\text { KKRK }\end{array}$ \\
\hline $\begin{array}{l}\text { Długość } \\
\text { trwania }\end{array}$ & $\begin{array}{l}\text { Od } 1 \text { miesiąca } \\
\text { do } 15 \text { lat }\end{array}$ & 25 lat & $\begin{array}{c}\text { Kara } \\
\text { dożywotnia }\end{array}$ & $\begin{array}{l}\text { - kara } \\
\text { dożywotnia } \\
-25 \text { lat - od } \\
1 \text { miesiąca } \\
\text { do } 15 \text { lat }\end{array}$ & $\begin{array}{l}\text { - kara } \\
\text { dożywotnia } \\
\text { - } 25 \text { lat - od } \\
1 \text { miesiąca } \\
\text { do } 15 \text { lat }\end{array}$ \\
\hline $\begin{array}{c}\text { Przepis } \\
\text { szczególny }\end{array}$ & Art. $37 \mathrm{KK}$ & - & - & $\begin{array}{l}\text { Art.42 } \\
\text { KKRK }\end{array}$ & $\begin{array}{l}\text { Art. } 42 \\
\text { KKRK }\end{array}$ \\
\hline $\begin{array}{c}\text { Częstość } \\
\text { agrożenia karą }\end{array}$ & Bardzo czessto & Bardzo rzadko & Bardzo rzadko & Rzadko & $\begin{array}{c}\text { Bardzo } \\
\text { często }\end{array}$ \\
\hline $\begin{array}{c}\text { Czy obejmuje } \\
\text { przymusową } \\
\text { pracę } \\
\text { więzienną }\end{array}$ & Nie & Nie & Nie & $\mathrm{Nie}$ & Tak \\
\hline
\end{tabular}

Obliczanie maksymalnej wysokości: iloczyn maksymalnej ustawowej liczby stawek i maksymalnej ustawowej wysokości jednej stawki; obliczanie minimalniej stawki: iloczyn minimalnej ustawowej liczy stawek i minimalnej ustawowej wysokości jednej stawki. 
Tabela 3: Kary aresztu

\begin{tabular}{|c|c|c|}
\hline Cecha & Kara aresztu & 구류 \\
\hline Podstawa prawna & Art. $18 \mathrm{KW}$ & Art. 41 KKRK \\
\hline Przepis szczególny & Art. $19 \mathrm{KW}$ & Art. 46 KKRK \\
\hline Wymiar & Od 5 do 30 dni & Od 1 do 30 dni \\
\hline Częstość zagrożenia & Bardzo często & Bardzo rzadko \\
\hline Dodatkowe informacje & $\begin{array}{c}\text { Często wymieniana w ustawie } \\
\text { jako kara grożąca za popełnienie } \\
\text { wykroczenia, ale jest stosowana } \\
\text { w ostateczności }\end{array}$ \\
\hline
\end{tabular}

Tabela 4: Kary (lub środki karne) związane z utratą praw:

\begin{tabular}{|c|c|c|c|c|}
\hline Cecha & $\begin{array}{c}\text { Pozbawienie } \\
\text { praw } \\
\text { publicznych }\end{array}$ & $\begin{array}{c}\text { Zakaz zajmowania } \\
\text { określonego } \\
\text { stanowiska(...) }\end{array}$ & 자격상실 & 자격정지 \\
\hline $\begin{array}{c}\text { Podstawa } \\
\text { prawna }\end{array}$ & Art. 39 KK & Art. 39. KK & Art. 41 KKRK & Art. 41 KKRK \\
\hline $\begin{array}{c}\text { Częstość } \\
\text { zagrożenia }\end{array}$ & Powiązany z kara & Powiązany z kara & $\begin{array}{c}\text { Zgodnie z art. 43 } \\
\text { KKRK }\end{array}$ & rzadko \\
\hline $\begin{array}{c}\text { Kara/środek } \\
\text { karny }\end{array}$ & Środek karny & Środek karny & $\begin{array}{c}\text { Kara } \\
\text { niesamodzielna }\end{array}$ & Kara \\
\hline $\begin{array}{c}\text { Dodatkowe } \\
\text { informacje }\end{array}$ & $\begin{array}{c}\text { Szczególny }- \\
\text { art. 41 KK }\end{array}$ & $\begin{array}{c}\text { Orzekana } \\
\text { dodatkowo w przy- } \\
\text { padku skazania na } \\
\text { karę sahyóng, lub } \\
\text { dożywotnie kary } \\
\text { pozbawienia } \\
\text { wolności }\end{array}$ & $\begin{array}{c}\text { Przzepisy } \\
\text { Art. 43 i art. 44 } \\
\text { KKRK }\end{array}$ \\
\hline
\end{tabular}

Tabela 5: Kary pozbawienia życia:

\begin{tabular}{|c|c|c|}
\hline Cecha & Kara śmierci & 사형 \\
\hline Podstawa prawna & Art. 30§2 KK69 & Art. 41 KKRK \\
\hline $\begin{array}{c}\text { Czy nadal istnieje w } \\
\text { systemie prawnym? }\end{array}$ & $\begin{array}{c}\text { Nie (zastąpiona dożywotnim } \\
\text { pozbawieniem wolności) }\end{array}$ & Tak \\
\hline Sposób wykonania & Przez powieszenie & Przez powieszenie \\
\hline Częstość zagrożenia & $\begin{array}{c}\text { Jako kara wyjątkowa za } \\
\text { najcięższe przestępstwa }\end{array}$ & $\begin{array}{c}\text { Najcięższe przestępstwa } \\
\text { bardzo rzadko }\end{array}$ \\
\hline
\end{tabular}


Tabela 6: Kary/środki karne związane z konfiskatą mienia

\begin{tabular}{|c|c|c|c|}
\hline Cecha & $\begin{array}{c}\text { Przepadek przedmiotów } \\
\text { z KK }\end{array}$ & $\begin{array}{c}\text { Przepadek przedmiotów } \\
\mathbf{z ~ K W}\end{array}$ & 몰수 \\
\hline $\begin{array}{c}\text { Podstawa } \\
\text { prawna }\end{array}$ & Art. 39 KK & Art. 28§1 KW & Art. 41 KKRK \\
\hline $\begin{array}{c}\text { Przepis } \\
\text { szczególny }\end{array}$ & Art. 44 KK i art. 45 KK & Art. 30 KW & Art. 48 i art. 49. KKRK \\
\hline $\begin{array}{c}\text { Częstość } \\
\text { zagrożenia }\end{array}$ & W związku z karą & W związku z karą & $\begin{array}{c}\text { Zgodnie z art. } 48 . \\
\text { KKRK }\end{array}$ \\
\hline $\begin{array}{c}\text { Kara/środek } \\
\text { karny }\end{array}$ & Środek karny & Środek karny & Kara \\
\hline
\end{tabular}

$\mathrm{Z}$ analizy poszczególnych kar wynikają następujące wnioski:

1. Koreański system co prawda przewiduje kilka odmian kar pozbawienia wolności, ale rozróżnienie opiera na innej podstawie niż ustawodawca polski. W polskim systemie kryterium rozróżnienia jest wysokość (długość trwania) kary pozbawienia wolności, a w systemie koreańskim - to, czy przewiduje dodatkowo pracę więzienną, czy nie. Zarówno jingyŏk jak i gŭmgo mogą obejmować okres od 3 miesięcy do dożywotniego pozbawienia wolności.

2. Kara śmierci istniejąca w Polsce na mocy KK69 była wykonywana w ten sam sposób co sahyŏng, a także zagrożone nią były przestępstwa o podobnym ciężarze gatunkowym.

3. Podczas gdy jagyŏk sangshil i jagyŏk jŏngji są sankcjami o randze kar w prawie koreańskim, w prawie polskim instytucje podobne są jedynie środkami karnymi. To samo tyczy się molsu i przepadku przedmiotów z KK i KW.

\section{Wstępne uwagi do thumaczenia koreańsko-polskiego}

Poprzednie rozdziały w sposób wyraźny wskazały na wiele istotnych różnic między tekstami paralelnymi, jakimi są kodeksy obu państw, jak i różnice w systematyce prawa i kar. To co w Republice Korei jest osobną karą, to w polskim prawie karnym jest jedynie środkiem karnym lub wręcz w ogóle nie jest przewidziane przez ustawę. Dlatego też tłumaczenie wymaga ostrożności, gdyż, w zależności od odbiorcy, tłumaczenie może wydać się niezrozumiałe czy nawet mylące. Kolejna trudność wynika z odległości kultur prawnych, jak i kultur w ogóle. Egzotyczna para językowa, jaką bez wątpienia jest para koreańsko-polska przysparza trudności także ze względu na swą geograficzną, polityczną czy historyczną wzajemną niezależność. Polski prawnik, mający wykształcenie w zakresie rodzimego prawa, może mieć trudności z rozumieniem niektórych instytucji i pojęć koreańskich, jeśli zignoruje niuanse kulturowe i językowe. 
Tłumaczenie aktu prawnego może być dokonywane ze względu na różnych odbiorców. Trzy typy odbiorców zostały zaproponowane przez Kierzkowską (Kierzkowska 2002, 88). Potencjalnym odbiorcą thumaczenia może być osoba, która:

1. posiada wykształcenie albo wiedzę prawniczą i zna albo jest gotowa poznać realia i kulturę języka docelowego - odbiorca bliski,

2. stosuje własną terminologię (np. wydawnictwo, agencja tłumaczeń) - odbiorca samookreślony,

3. nie posiada wykształcenia prawniczego i nie zna ani nie wykazuje chęci poznania realiów języka źródłowego - odbiorca daleki (Kierzkowska 2002, 88).

$\mathrm{Na}$ potrzeby tłumaczenia $\mathrm{w}$ tej pracy zmodyfikowano te typy. Pominięto tłumaczenie dla odbiorcy samookreślonego i skupiono się na odbiorcy bliskim i dalekim, z tym że kryterium rozróżnienia na odbiorcę bliskiego i dalekiego jest trochę bardziej rygorystyczne, co w praktyce doprowadziło do wyróżnienia czterech typów odbiorców:

\begin{tabular}{|l|l|l|l|l|}
\hline \multicolumn{1}{|c|}{ Odbiorca } & $\begin{array}{l}\text { Odbiorca bliski } \\
\text { A }\end{array}$ & Odbiorca bliski B & $\begin{array}{l}\text { Odbiorca daleki } \\
\text { A }\end{array}$ & Odbiorca daleki B \\
\hline $\begin{array}{l}\text { Przykład } \\
\text { odbiorcy }\end{array}$ & $\begin{array}{l}\text { Przedsiębiorca } \\
\text { prowadzący } \\
\text { działalność w } \\
\text { Korei } \\
\text { Południowej }\end{array}$ & $\begin{array}{l}\text { Prawnik } \\
\text { jednorazowo/pośre } \\
\text { dnio mający do } \\
\text { czynienia ze } \\
\text { sprawą }\end{array}$ & $\begin{array}{l}\text { Badacz kultury } \\
\text { Korei }\end{array}$ & $\begin{array}{l}\text { Czytelnik } \\
\text { książki/artykułu, } \\
\text { niezainteresowany } \\
\text { realiami } \\
\text { koreańskimi }\end{array}$ \\
\hline $\begin{array}{l}\text { Znajomość } \\
\text { prawa }\end{array}$ & Posiada & Posiada & Nie posiada & Nie posiada \\
\hline $\begin{array}{l}\text { Znajomość } \\
\text { realiów języka } \\
\text { źródłowego }\end{array}$ & $\begin{array}{l}\text { Posiada/planuje } \\
\text { posiadać }\end{array}$ & Nie posiada & $\begin{array}{l}\text { Posiada/planuje } \\
\text { posiadać }\end{array}$ & Nie posiada \\
\hline
\end{tabular}

Z tabeli wynika, że odbiorcą bliskim jest zawsze osoba posiadająca wiedzę z zakresu prawa (języka docelowego). To, czy będzie odbiorcą bliskim typu A (bliższym), czy typu B (dalszym) zależy od tego, czy zna realia języka źródłowego czy też nie. Poza tym, kolejną różnicą między odbiorcami bliskimi niech będzie założenie, że odbiorca bliski B pragnie zapoznać się jedynie $\mathrm{z}$ przetłumaczonymi pojęciami, a nie $\mathrm{z}$ treścią całego aktu prawnego, jakim jest KKRK, a więc nie zapozna się w ogóle z przepisami szczególnymi ustawy. Odbiorcą dalekim jest zawsze osoba bez wykształcenia albo znajomości prawa języka docelowego. Wśród takich odbiorców znaleźć mogą się jednak odbiorcy, których można podzielić dalej na znających realia języka źródłowego (odbiorca daleki A) i nie posiadających takiej wiedzy (odbiorca daleki B). W zależności od odbiorcy należy przyjąć różne strategie thumaczeniowe. 


\section{Nazewnictwo kar w aspekcie tlumaczeniowym koreańsko-polskim}

\section{Sahyŏng (사형)}

Porównując pola znaczeniowe pierwszej kary z art. 41. KKRK, jaką jest sahyŏng, wydawać się może, że odpowiednim ekwiwalentem dla tego pojęcia jest polskie pojęcie „kara śmierci”. W przypadku obu z tych kar chodzi przecież o pozbawienie życia skazanego, nawet dokonywane w ten sam sposób - przez powieszenie. Jedyną różnicą jest fakt, że kara śmierci to w Polsce relikt z czasów obowiązywania KK69, a sahyŏng w KKRK jest przynajmniej teoretycznie karą obecnie istniejącą. Nie wzbudza to jednak wątpliwości co do istoty kary. Dla odbiorcy dalekiego (A i B) wartościowym mogłoby się wydawać dodanie wzmianki, że kara śmierci dokonywana jest przez powieszenie. Odbiorca daleki jako nie posiadający wykształcenia prawniczego ma prawo nie wiedzieć w jaki sposób wykonuje się karę śmierci, tym bardziej, że kara ta nie istnieje obecnie w systemie prawnym języka docelowego, jakim jest język polski. Nie jest konieczne czynienie takiej wzmianki w przypadku odbiorcy bliskiego, gdyż jako znający prawo języka docelowego, wie, że kara śmierci w tym systemie dokonywana była przez powieszenie, a $\mathrm{w}$ prawie koreańskim nie ma $\mathrm{w}$ tym przypadku żadnej różnicy. W przypadku odbiorcy bliskiego A można zastosować ekwiwalent „kara śmierci”, gdyż w analogiczny sposób wyraża się zagrożenie karą w polskich aktach prawnych, bez opisowego wyjaśniania, czym owa kara dokładnie jest. Wyjaśnienie takie znajduje się w przepisach szczególnych. $Z$ drugiej strony, problem pojawia się w przypadku odbiorcy bliskiego $\mathrm{B}$, który $\mathrm{z}$ racji posiadania wiedzy prawniczej może mieć wątpliwości co do sposobu wykonania kary, mając świadomość, że w systemach prawnych na świecie karę tę wykonuje się też na przykład przez rozstrzelanie, krzesło elektryczne, śmiertelny zastrzyk itd. Dodanie sformułowania ,przez powieszenie” nie uczyni tekstu zbyt rozwlekłym czy mało czytelnym, więc w przypadku tego odbiorcy można zastosować któryś z dwóch proponowanych ekwiwalentów. Proponowane tłumaczenie przedstawia się więc następująco:

\begin{tabular}{|l|l|l|l|l|}
\hline Termin & OBA & OBB & ODA & ODB \\
\hline sahyŏng (사형) & „Kara śmierci” & $\begin{array}{c}\text { „Kara śmierci” lub } \\
\text { „Kara śmierci } \\
\text { przez } \\
\text { powieszenie” }\end{array}$ & „Kara śmierci przez \\
powieszenie”
\end{tabular}

\section{Jingyø̆k (징역)}

Kara ta przysparza tłumaczowi więcej trudności. Termin jingyŏk jest bowiem terminem bezekwiwalentowym, gdyż w polskim prawnie karnym nie istnieje kara odpowiadająca w zadowalającym stopniu tej karze, a więc nie można użyć istniejącego już w polskim prawie karnym pojęcia dla przethumaczenia tego terminu. $Z$ jednej strony kara ta wiąże się z pozbawieniem wolności skazanego, a więc przywodzi na myśl karę pozbawienia wolności z KK, z drugiej strony istnieją pewne zasadnicze różnice. Po pierwsze, kara jingyŏk już ze swojej natury jest karą związaną z wykonywaniem przymusowej pracy podczas odbywania kary pozbawienia wolności, a kara pozbawienia wolności z KK nie 
przewiduje ze swojej natury takiej konieczności. Po drugie, długość kary jingyŏk może wynosić minimalnie od miesiąca do 15 lat, 25 lat lub być karą dożywotnią. Nie jest odrębną karą kara o dłuższym wymiarze, jak to jest w przypadku prawa polskiego. W przypadku tej kary należy zastosować, w zależności od odbiorcy, różne techniki zapewniania ekwiwalentów. Dla odbiorcy bliskiego - podstawowym członem nazwy w języku docelowym będzie „kara pozbawienia wolności” - jako termin znany z KK, ale by uniknąć efektu „fałszywego przyjaciela” należy uzupełnić tłumaczenie o wyrażenie „z przymusową pracą więzienną", a więc zastosować ekwiwalent seminaturalny. Sposób odbywania tej kary nie wymaga dalszej charakterystyki jeśli mamy do czynienia zodbiorcą bliskim A, gdyż wyjaśnienia co do odbywania kary znajdują się w przepisach szczególnych, z którymi z założenia odbiorca A zapoznał się lub chce się zapoznać. W przypadku tego odbiorcy również zależy nam na zwięzłości tekstu, więc proponowane tłumaczenie wydaje się wystarczające. Odbiorca bliski B może zastanawiać się jak przymusowa praca ma wyglądać i jednocześnie nie zapoznaje się z koreańskimi realiami ani nie poszerza swojej wiedzy $\mathrm{w}$ inny sposób niż przez zapoznanie się $\mathrm{z}$ tłumaczeniem. W tym przypadku zastosowanie mógłby mieć ekwiwalent opisowy, a tłumaczenie brzmiałoby „kara pozbawienia wolności połączona z wykonywaniem przymusowej pracy w zakładzie karnym”. Dla odbiorcy dalekiego A prawdopodobnie wystarczy zastosowanie tego samego ekwiwalentu seminaturalnego, co w przypadku odbiorcy bliskiego A. Skłonny poznać lub już znający koreańskie realia odbiorca daleki A nie potrzebuje ekwiwalentu opisowego. Odbiorca daleki B również nie potrzebuje dłuższej charakterystyki tej kary jako nie-prawnik, a więc co prawda z innych powodów niż ODA i OBA, ale i dla niego tłumaczenie „kara pozbawienia wolności z przymusową pracą" powinno być wystarczające. Podsumowując, proponowane thumaczenia dla terminu jingyŏk dla czterech rożnych odbiorców przedstawia się następująco:

\begin{tabular}{|c|c|c|c|c|}
\hline Termin & OBA & OBB & ODA & ODB \\
\hline jingyŏk & \multicolumn{3}{|c|}{$\begin{array}{c}\text { „Kara pozbawienia wolności z } \\
\text { przymusową pracą” }\end{array}$} & $\begin{array}{c}\text { „Kara pozbawienia wolności } \\
\text { połączona z wykonywaniem } \\
\text { przymusowej pracy w zakładzie } \\
\text { karnym” }\end{array}$ \\
\hline
\end{tabular}

\section{Gŭmgo (금고)}

Druga z kar związanych z pozbawieniem wolności skazanego nie obejmuje już przymusowej pracy więziennej, a więc bardziej przypomina karę pozbawienia wolności znaną $\mathrm{z} K \mathrm{KK}$, ale istnieją pewne różnice. Pierwsza dotyczy długości trwania kary, w tym samym aspekcie co jingyŏk. Druga z różnic to doniosłość tej kary. Jest to kara ze swej natury mniej dolegliwa niż jingyŏk, zdecydowanie rzadziej zagrażająca za popełnienie przestępstwa, a co za tym idzie wzbudzać powinna inne odczucia u odbiorcy bliskiego niż kara pozbawienia wolności z KK. By nie wzbudzać wątpliwości u odbiorcy bliskiego $B$, zastosować należy ekwiwalent seminaturalny, który pozwoli wyróżnić gŭmgo na tle innych kar pozbawienia wolności funkcjonujących w Republice Korei. Co do odbiorcy dalekiego, który karę pozbawienia wolności postrzega $\mathrm{w}$ takim sensie, w jakim funkcjonuje to pojęcie $\mathrm{w}$ polskim języku potocznym, wystarczy tłumaczenie ,kara pozbawienia wolności”. To samo tyczy się odbiorcy bliskiego A - charakter kary wynika z przepisów szczególnych. 


\begin{tabular}{|c|c|c|c|c|}
\hline Termin & OBA & OBB & ODA & ODB \\
\hline gümgo & \multicolumn{3}{|c|}{ „Kara pozbawienia wolności” } & $\begin{array}{c}\text { „Kara pozbawienia wolności bez } \\
\text { przymusowej pracy w zakładzie } \\
\text { karnym” }\end{array}$ \\
\hline
\end{tabular}

\section{Jagyŏk sangshil (자격상실)}

Thumaczenie tego terminu przysparza pewnych trudności ze względu na fakt, że w prawie polskim kara taka nie istnieje, istnieje za to środek karny o podobnym charakterze (pozbawienie praw publicznych z art. 40 KK). Podobnym, znaczy „honorowym” - wyraźniej było to wyrażone w Kodeksie Karnym z 1932 roku, kiedy to środek karny związany z pozbawieniem praw publicznych nosił nazwę ,pozbawienie praw publicznych i obywatelskich praw honorowych" (Gardocki 2010, 171). Automatycznie nasuwa się więc skojarzenie z koreańską karą , honorową" - myŏngyehyŏng. Dla nie-prawnikow kwestia kary i środka karnego nie ma większego znaczenia, ale tłumacz musi być precyzyjny jeśli chodzi o odbiorców bliskich. Odbiorca bliski B po pierwsze nie może mylić kary ze środkiem karnym (stąd określenie „kara” w brzmieniu thumaczenia), ale z drugiej strony musi wiedzieć, że jagyŏk sangshil nie orzeka się samodzielnie, a tylko w związku z orzeczeniem innych kar (art. 43 KKRK). Po raz kolejny dla tego odbiorcy zastosowano ekwiwalent opisowy. Proponowane thumaczenie to:

\begin{tabular}{|c|c|c|c|c|}
\hline Termin & OBA & OBB & ODA & ODB \\
\hline jagyŏk sangshil & $\begin{array}{c}\text { „Kara } \\
\text { dożywotniego } \\
\text { pozbawienia praw } \\
\text { publicznych” }\end{array}$ & $\begin{array}{c}\text { niesamodzielna } \\
\text { dotycząca } \\
\text { dożywotniego } \\
\text { pozbawienia praw } \\
\text { publicznych” }\end{array}$ & $\begin{array}{c}\text { "Dożywotnie pozbawienie } \\
\text { praw publicznych” }\end{array}$ \\
\hline
\end{tabular}

\section{Jagyŏk jŏngji (자격정지)}

Różnice między jedną z kar „honorowych” a drugą, wskazane w poprzednim rozdziale, muszą mieć swoje odzwierciedlenie $\mathrm{w}$ thumaczeniu. W związku $\mathrm{z}$ tym, proponowane thumaczenie dla tego terminu to:

\begin{tabular}{|c|c|c|c|c|}
\hline Termin & OBA & OBВ & ODA & ODB \\
\hline jagyŏk jŏngji & $\begin{array}{r}\text { „Kara zay } \\
\mathrm{P} \\
\text { „Kara tymc } \\
\text { pray }\end{array}$ & $\begin{array}{l}\text { v prawach } \\
\text { " } \\
\text { pozbawienia } \\
\text { ych" }\end{array}$ & \multicolumn{2}{|c|}{$\begin{array}{l}\text { „Tymczasowe zawieszenie } \\
\text { w prawach publicznych" }\end{array}$} \\
\hline
\end{tabular}




\section{Pŏlgŭm (벌금) i gwaryo (과료)}

Tłumaczenie wyżej wymienionych terminów jest oczywiste tylko częściowo. Pŏlgŭm jest karą pieniężną przywodzącą na myśl grzywnę z KK, ale może być to mylące, ponieważ karą pieniężną w KKRK jest również gwaryo. W celu uniknięcia pomyłki należy rozróżnić kary pieniężne także w tłumaczeniu. Zarówno dla odbiorców bliskich jak i dalekich wydaje się być istotne o jak wysokiej karze pieniężnej mowa w przypadku poszczególnych pojęć - musi bowiem istnieć uzasadnienie dla faktu, że w koreańskim prawie karnym funkcjonują dwa określenia związane $\mathrm{z}$ karą pieniężną. Różnica w tłumaczeniu dla odbiorcy dalekiego i dla odbiorcy bliskiego będzie nieznaczna odbiorca bliski musi bowiem wiedzieć, że ma do czynienia z karą kryminalną a nie inną sankcją. Zatem pojęcia pŏlgŭm i gwaryo przetłumaczono następująco:

\begin{tabular}{|c|c|c|c|c|}
\hline Termin & OBA & OBB & ODA & ODB \\
\hline pŏlgŭm & $\begin{array}{r}\text { „Kara gr } \\
\text { wymiarze’ } \\
\text { drug }\end{array}$ & $\begin{array}{l}\text { wyższym } \\
\text { a grzywny } \\
\text { nia" }\end{array}$ & \multicolumn{2}{|c|}{ „Wyższy wymiar grzywny” } \\
\hline gwaryo & $\begin{array}{r}\text { „Kara g } \\
\text { wymiarze' } \\
\text { pierv }\end{array}$ & $\begin{array}{l}\text { niższym } \\
\text { a grzywny } \\
\text { pnia" }\end{array}$ & \multicolumn{2}{|c|}{ „Niższy wymiar grzywny” } \\
\hline
\end{tabular}

\section{Guryu (구류)}

Trzecia $\mathrm{z}$ kar związanych $\mathrm{z}$ pozbawieniem wolności, ale najmniej dolegliwa i teoretycznie najkrótsza, kojarzy się z instytucją podobną w polskim prawie wykroczeń aresztem. Powodem, dla którego dostrzeżono analogię jest długość tej kary i jej charakter oraz ciężar gatunkowy przestępstw, za których popełnienie owa kara grozi. Guryu jednak jest karą znajdującą się w KKRK, a więc znajdującą się w tym samym katalogu co kary pozbawienia wolności, kara śmierci i inne z art. 41 KKRK. Kara aresztu w Polsce jest karą za wykroczenia, a więc za czyny inne niż przestępstwa, podczas gdy guryu jak najbardziej jest karą za przestępstwa. Należy poczynić taką uwagę w przypadku odbiorcy bliskiego B:

\begin{tabular}{|c|c|c|c|c|}
\hline Termin & OBA & OBB & ODA & ODB \\
\hline$g u r y u$ & „Kara aresztu” & $\begin{array}{c}\text { „Kara aresztu za } \\
\text { przestępstwa” }\end{array}$ & „Areszt” lub „kara aresztu” \\
\hline
\end{tabular}

\section{Molsu (몰수)}

Ostatnia z kar, podobnie jak jagyŏk sangshil, na swój sposób przypomina środek karny, ale na gruncie KKRK nim nie jest i nie może być tak traktowana, a co najwyżej takie nawiązanie może ułatwić polskiemu odbiorcy wyobrażenie sobie istoty tej kary. Została ona omówiona $\mathrm{w}$ poprzednim rozdziale. Proponowane opcje tłumaczenia dla odbiorcy bliskiego są dwie. Jedna $\mathrm{z}$ nich sugeruje podobieństwo do środka karnego z KK i KW („kara przepadku przedmiotów”), a druga takiego podobieństwa nie sugeruje (,kara 
konfiskaty” dla odbiorcy A i „kara niesamodzielna konfiskaty” dla odbiorcy B). W przypadku odbiorcy dalekiego wystarczające jest sformułowanie „konfiskata”.

\begin{tabular}{|c|c|c|c|c|}
\hline Termin & OBA & OBB & ODA & ODB \\
\hline Molsu - opcja 1 & „Kara przepadku przedmiotów” & „Konfiskata” \\
\hline Molsu- opcja 2 & $\begin{array}{c}\text { „Kara } \\
\text { konfiskaty” }\end{array}$ & $\begin{array}{c}\text { „Kara } \\
\text { niesamodzielna } \\
\text { konfiskaty” }\end{array}$ & Nie dotyczy \\
\hline
\end{tabular}

\section{Podsumowanie}

W ramach pracy udało się przybliżyć polskiemu odbiorcy w pewnym stopniu specyfikę koreańskiego prawa karnego materialnego, a także zaproponować nazewnictwo kar kryminalnych w KKRK w aspekcie tłumaczeniowym koreańsko-polskim.

Zastrzec jednak należy, że materia, jaką jest prawo karne materialne, czy wręcz sama nauka o karze, ma o wiele szerszy zakres niż przedstawiony $\mathrm{w}$ ramach pracy. $\mathrm{W}$ związku z tym przydatne wydaje się dalsze zagłębienie się w ową tematykę, w Polsce niemalże nie poruszaną. Ciekawym problemem z zakresu koreańskiego prawa karnego materialnego jest katalog przestępstw - o wiele bogatszy niż katalog kar. Wykazuje on wiele różnic $\mathrm{w}$ porównaniu do polskiego prawa, a także wiele zastanawiających podobieństw.

Znajomość prawa karnego państw obcych nie jest wiedzą przydatną samą w sobie. Prawo karne powinno stanowić przedmiot zainteresowania nie tylko prawników i thumaczy, ale także badaczy kultury, ze względu na to, że prawo karne ma na celu chronić dobra prawne ważne dla danej społeczności, jaką jest naród. Jest odzwierciedleniem długoletnich tradycji oraz mentalności społeczeństwa, dla którego i przez które zostało uchwalone. W przypadku Korei silny wpływ na prawo karne miał konfucjanizm (Choi 2005, 177). Tłumaczenie prawnicze dotyczące pary językowej koreańsko-polskiej zyskuje na znaczeniu ze względu na postępującą globalizację oraz coraz częstsze kontakty gospodarcze. Szczególnej uwagi wymaga więc komparatystyka całych porządków prawnych, a poruszenie kwestii jednej tylko gałęzi prawa, jaką jest prawo karne materialne, jest jedynie małym do tego przyczynkiem. 


\section{Bibliografia}

Bojarski, Tadeusz. 2012. Polskie prawo karne. Zarys części ogolnej. Warszawa: LexisNexis. Burzyński, Paweł. 2008. Ustawowe określenie sankcji karnej. Warszawa: Wolters Kluwer Polska.

Choi, Chongko. 2005. Law and Justice in Korea. Seul: University of Hawai'i Press.

Delisle, Jean, i Hannelore Lee-Jahnke (red.). 1999. Terminologie de la Traduction: Translation terminology. Amsterdam: John Benjamins Publishing Company.

Gardocki, Lech. 2010. Prawo karne. Warszawa: Wydawnictwo C. H. Beck.

Giętkowski Radosław. 2007. Kara ograniczenia wolności w polskim prawie karnym. Warszawa: Wolters Kluwer Polska.

Jopek-Bosiacka, Anna. 2006. Przekład prawny i sadowy. Warszawa: Wydawnictwo Naukowe PWN.

Kaczmarek, Karolina, i Aleksandra Matulewska. 2008. Wykładnia normy prawnej a metodologia przekładu. W Rocznik Przekładoznawczy, t. 3/4, ss. 81-94.

Kierzkowska, Danuta. 2002. Ttumaczenie prawnicze. Warszawa: Wydawnictwo Translegis.

Kim, Suntae, i Yŏngmin Jang. 2000. Hyŏngbŏp chongron (형법총론). Seul.

Kim, Suntae, Inyŏng Lee, i Kyŏngjae Lee. 2007. Hyŏngsa jŏngchaek (형사정책). Seul.

Lukszyn, Jurij (red.). 1993. Tezaurus terminologii translatorycznej. Warszawa: Wydawnictwo Naukowe PWN.

Marek, Andrzej, i Jerzy Lachowski. 2011. Prawo karne. Zarys problematyki. Warszawa: Wolters Kluwer Polska.

Marek, Andrzej. 2012. Prawo wykroczeń materialne i procesowe. Warszawa: Wydawnictwo C. H. Beck.

Neubert, Albrecht, i Gregory M. Shreve. 1992. Translation as text. Kent: Kent State University Press.

Ogarek- Czoj, Halina, Romuald Huszcza, i Gunn Young Choi. 2007. Podręcznik języka koreańskiego. Część I. Warszawa: Wydawnictwo Akademickie Dialog.

Ryu, Paul Kichyun. 1957. The New Korean Criminal Code of October 3, 1953 - An Analysis of Ideologies Embedded in It. Journal of Criminal Law and Criminology, t. 43, Evanston.

Wronkowska, Sławomira. 2002. Podstawowe pojęcia prawa i prawoznawstwa, Poznań: Ars boni et aequi.

Zoll Andrzej, i Włodzimierz Wróbel. 2010. Polskie prawo karne. Czesść ogólna, Kraków: Wydawnictwo Znak. 
